\title{
Analisis Pengaruh Kepemimpinan dan Motivasi Terhadap Turnover Intention Karyawan dengan Komitmen Organisasi Sebagai Variabel Mediasi Rumah Sakit Islam Siti Rahmah
}

\author{
Yori Rahmadianti ${ }^{1}$, Syukri Lukman², Rima Semiarty ${ }^{3}$
}

\begin{abstract}
Abstrak
Fenomena yang sering kali terjadi adalah kinerja suatu perusahaan yang telah demikian bagus dapat dirusak, baik secara langsung maupun tidak langsung oleh berbagai perilaku karyawan yang sulit dicegah terjadinya. Salah satu bentuk perilaku karyawan tersebut adalah keinginan berpindah (Turnover Intentions) yang berujung pada keputusan karyawan untuk undur diri dari pekerjaannya. Turnover Intention dapat dipengaruhi oleh kepemimpinan, motivasi kerja dan komitmen organisasi. Tujuan: Mengetahui pengaruh kepemimpinan, motivasi kerja terhadap turnover intention dengan dimediasi oleh komitmen organisasi. Penelitian dilakukan di Rumah Sakit Islam Siti Rahmah pada bulan November 2017 sampai Juli 2018. Metode: penelitian ini adalah explanatory research dengan pendekatan kuantitatif. Jumlah sampel adalah 208 orang. Teknik pengambilan sampel ialah proportionate stratified random sampling yaitu karyawan tetap dan kontrak. Instrumen penelitian ini menggunakan kuesioner dengan teknik analisis SEM berbasis varian yaitu Partial Least Square. Hasil: Ada pengaruh negatif dan signifikan kepemimpinan dan motivasi kerja terhadap turnover intention dengan dimediasi oleh komitmen organisasi.Simpulan: Kepemimpinan, motivasi kerja dan komitmen organisasi memiliki pengaruh negatif terhadap turnover intention karyawan. Kepemimpinan dan motivasi kerja memiliki pengaruh yang positif terhadap komitmen organisasi di Rumah Sakit Islam Siti Rahmah.
\end{abstract}

Kata Kunci: kepemimpinan, motivasi kerja, komitmen organisasi, turnover intention

\section{Abstract}

The phenomenon that often happens is the performance of a company that has been good can be damaged, the occurrence can be directly or indirectly by a variety of employee behavior is difficult to prevent. One of these employee behaviors is turnover intentions that lead to employee decisions to resign from their work. Turnover Intention can be influenced by leadership, work motivation and organizational commitment. Objectives: To determined the influence of leadership, work motivation for turnover intention with mediated by organizational commitment. The research was conducted at Siti Rahmah Islamic Hospital in November 2017 - July 2018. Methods:This research type was explanatory research with quantitative approach. The samples were 208 with Proportionate Stratified Random Sampling technique and those are permanent and contract employee. The instrument of this research was questionnaires with analytical techniques used SEM-based variants namely Partial Least Square. Results: There was negative and significant influence of leadership and work motivation toward turnover intention with mediated by organizational commitment. Conclusions: The leadership, work motivation and organizational commitment had a negative influence on employee turnover intention. The leadership and work motivation have a positive influence on organizational commitment.

Keywords : leadership, work motivation, organizational commitment, turnover intention

Affiliasi penulis: ${ }^{1}$ Rumah Sakit Islam Siti Rahmah, Padang, ${ }^{2}$ Fakultas Ekonomi, Universitas Andalas, ${ }^{3}$ IImu Kesehatan Masyarakat, Fakultas Kedokteran, Universitas Andalas, Padang.
Korespondensi: Yori Rahmadianti,

Email:yorirahmadianti@gmail.com

Telp: +6282388210464 


\section{PENDAHULUAN}

Rumah sakit adalah satu sarana dalam menyelenggarakan pelayanan kesehatan perorangan secara paripurna yang menyediakan pelayanan rawat inap, rawat jalan, dan gawat darurat. Fungsi utama rumah sakit adalah melayani masyarakat yang membutuhkan pelayanan kesehatan, terutama sebagai tempat untuk pelayanan medis, pencegahan dan pendidikan kesehatan, dan juga sebagai usaha perawatan, usaha pendidikan dan latihan serta sebagai tempat rujukan dan penelitian. Dalam menjalankanfungsinya rumah sakit harus didukungan dengan sumber daya yang baik. 1

Rumah sakit dituntut untuk memiliki pemimpin yang mampu menentukan arah dan cara mengembangkan visi organisasi kedepannya serta harus mampu menyatukan orang-orang dengan mengkomunikasikan visi tersebut. Hal ini dikarenakan bahwa bawahan bekerja selalu bergantung pada pimpinan. ${ }^{2}$

Seorang pemimpin juga harus mampu menyikapi perkembangan zaman, dengan kemampuan yang mampu membuat kebijakan-kebijakan baru untuk mengantisipasi munculnya fenomena-fenomena yang dapat menentukan kinerja karyawan. ${ }^{3}$ Organisasi akan lebih hidup jika memiliki pemimpin yang baik dan mampu memberikan motivasi untuk meningkatkan loyalitas kepada bawahanya sehingga mereka merasa bermanfaat bagi organisasi tersebut. ${ }^{4}$

Motivasi adalah pemberian daya penggerak yang menciptakan kegairahan seseorang agar mereka mau bekerja sama, bekerja efektif dan terintegrasi dengan segala daya upayanya untuk mencapai kepuasaan. Selain motivasi juga diperlukan komitmen organisasi, untuk membangun kerjasama, memupuk semangat kerja dan menciptakan loyalitas pada peruasahaan. komtmen yang tinggi terhadap perusahaan akan membawa dampak positif bagi perusahaan. ${ }^{5}$

Fenomena yang sering kali terjadi adalah kinerja suatu perusahaan yang telah demikian bagus dapat dirusak, baik secara langsung maupun tidak langsung oleh berbagai perilaku karyawan yang sulit dicegah terjadinya. Salah satu bentuk perilaku karyawan tersebut adalah keinginan berpindah (Turnover Intentions) yang berujung pada keputusan karyawan untuk undur diri dari pekerjaannya. ${ }^{6}$

\section{METODE}

Jenis penelitian ini adalah explanatory research, untuk melihat pengaruh antar dimensi dan dimensi lain atau variabel dengan variabel lain dengan pendekatan Kuantitatif. Dalam hal ini, melihat pengaruh antara gaya kepemimpinan, Motivasi Kerja dan Komitmen Organisasi terhadap Turnover Intention Karyawan di Rumah Sakit Islam Siti Rahmah. Penelitian ini dilakukan pada bulan November 2017 sampai Juli 2018. Populasi adalah seluruh karyawan. Pengambilan sampel menggunakan Proportionate Stratified Random Sampling. Jumlah sampel penelitian diambil menggunakan rumus slovin dengan jumlah sampel 208 karyawan. Instrumen penelitian yang digunakan berupa lembar checklist. $^{7}$

Analisis data menggunakan pendekatan Partial Least Square (PLS). PLS adalah model persamaan Structural Equation Modeling (SEM) yang berbasis komponen atau varian. PLS adalah membantu peneliti untuk tujuan prediksi. Model formalnya mendefinisikan variabel laten adalah linear agregat dari indikatorindikatornya. Weight estimate untuk menciptakan komponen skor variabel laten didapat berdasarkan bagaimana outer model (model pengukuran yaitu hubungan antara indikator dengan konstruknya) dan inner model (model struktural yang menghubungkan antar variabel laten) ${ }^{8}$

\section{HASIL}

Karakteristik responden dalam penelitian ini ditunjukkan dalam Tabel 1, dimana mayoritas responden memiliki umur antara 20-30 tahun yaitu sebanyak 132 orang (63,5\%). Distribusi frekuensi jenis kelamin, mayoritas responden adalah berjenis kelamin perempuan yaitu sebanyak 151 orang (72,6\%), sementara sisanya sebanyak 57 orang $(27,4 \%)$ adalah laki-laki. Terdapat sebanyak 104 orang (50\%) responden dengan kategori karyawan tetap, dan sebanyak 104 orang (50\%) responden dengan kategori karyawan kontrak.

Berdasarkan distribusi frekuensi status pernikahan, kebanyakan responden memiliki status pernikahan dengan kategori kawin yaitu sebanyak 117 orang (56,2\%). Karekteristik responden terakhir dibedakan atas jumlah tanggungan, dimana 
berdasarkan kategori ini, kebanyakan responden tidak memiliki tanggungan yaitu sebanyak 106 orang (51\%).

Karakteristik responden diketahui, maka selanjutnya dilakukan analisis outer model. Hal ini berguna untuk mengetahui hubungan antara variabel laten dengan indikatornya. Uji yang dilakukan pada outer model adalah convergent validity, composite reliability, average variance extracted (AVE) dan cronbach alpha ${ }^{8}$

\section{Analisis Validitas}

Hasil analisis validitas variabel kepemimpinan diukur dengan menggunakan 16 item pernyataan. Hasil análisis convergent validiy memperlihatkan bahwa semua item pernyataan memiliki factor loading lebih besar dari 0.7 yang berarti semua item pernyataan (16 item) dinyatakan valid atau dapat digunakan dalam mengukur variabel kepemimpinan. ${ }^{8}$

Hasil analisis validitas variabel motivasi kerja diukur dengan menggunakan 16 item pernyataan. Hasil análisis convergent validiy memperlihatkan bahwa semua item pernyataan memiliki factor loading lebih besar dari 0.7. Dengan demikian, dapat disimpulkan bahwa semua item pernyataan (16 item) dinyatakan valid atau dapat digunakan dalam mengukur variabel motivasi kerja. ${ }^{8}$

Hasil analisis validitas variabel komitmen organisasi diukur dengan menggunakan 3 indikator yaitu komitmen berkelanjutan, komitmen afektif, dan komitmen normatif. Ketiga indikator tersebut masingmasing diukur dengan menggunakan 5 item pernyataan. Hasil análisis convergent validiy memperlihatkan bahwa semua item pernyataan memiliki factor loading lebih besar dari 0.7 yang berarti semua item pernyataan (15 item) dinyatakan valid atau dapat digunakan dalam mengukur variabel komitmen organisasi. $^{8}$

Hasil analisis validitas variabel turnover intention diukur dengan menggunakan 5 item pernyataan. Hasil análisis convergent validiy memperlihatkan bahwa semua item pernyataan memiliki factor loading lebih besar dari 0.7. Dengan demikian, dapat disimpulkan bahwa semua item pernyataan (5 item) dinyatakan valid atau dapat digunakan dalam mengukur variabel turnover intention. ${ }^{8}$

\section{Analisis Reabilitas}

Hasil Analisis reabilitas bahwa variabel kepemimpinan memiliki composite reliablity sebesar 0.978, motivasi kerja 0.975 , komitmen organisasi 0.967 dan turnover intention 0.955. Dengan demikian dapat disimpulkan bahwa semua variabel penelitian memiliki composite reliability lebih besar dari nilai batas yang ditetapkan (cut-off) yaitu 0.7 sehingga dapat diartikan bahwa semua variabel penlitian adalah reliabel atau andal. ${ }^{8}$

\section{Average Variance Extracted (AVE)}

Hasil analisis AVE menunjukkan bahwa variabel kepemimpinan memiliki Average Variance Extracted (AVE) sebesar 0.737, motivasi kerja 0.719, komitmen organisasi 0.648 dan turnover intention 0.810. Dengan demikian dapat disimpulkan bahw semua variabel penelitian memiliki nilai AVE lebih besar dari nilai batas yang ditetapkan (cut-off) yaitu 0.5, sehingga dapat diartikan bahwa semua variabel penelitian dinyatakan dapat diterima. ${ }^{8}$

\section{Cronbach Alpha}

Cronbach alpha merupakan alat statistik yang digunakan untuk mengetahui kehandalan variabel. Suatu variabel diakatakan andal apabila memiliki nilai cronbach alpha lebih besar atau sama dengan $0.7 .^{9}$ Hasil analisis cronbach alpha menunjukkan bahwa variabel kepemimpinan memiliki cronbach alpha sebesar 0.976, motivasi kerja 0.972, komitmen organisasi 0.964 dan turnover intention 0.941. Dengan demikian dapat disimpulkan bahwa semua variabel penelitian memiliki nilai cronbach alpha lebih besar dari nilai batas yang ditetapkan (cut-off) yaitu 0.7 , sehingga dapat diartikan bahwa semua variabel penelitian dinyatakan andal. ${ }^{9}$

\section{Analisis Deskriptif}

\section{- Kepemimpinan}

Kepemimpinan adalah kemampuan mempengaruhi, mengarahkan dan mengawasi orang lain dalam melakukan pekerjaannya. Variabel ini diukur dengan menggunakan 16 item pernyataan. Berdasarkan hasil análisis convergent validity ditemukan semua item pernyataan valid.Hasil dapat 
dilihat bahwa skor rata-rata variabel kepemimpinan adalah 3,18 atau lebih tinggi dari nilai median yaitu 3.00. Hasil analisis deskriptif ini dapat diartikan bahwa menurut pegawai RSI Siti Rahmah Padang implementasi kepemimpinan masuk kedalam kategori efektif atau baik. ${ }^{10}$

\section{Motivasi Kerja}

Motivasi kerja adalah usaha yang dilakukan oleh karyawan dalam mengejar suatu tujuan. Variabel ini diukur dengan menggunakan 16 item pernyataan. Berdasarkan hasil análisis convergent validity ditemukan semua item pernyataan valid. Hasil dapat dilihat bahwa skor rata-rata variabel motivasi kerja adalah 2,97 atau lebih rendah dari nilai median yaitu 3.00. Hasil analisis deskriptif ini dapat diartikan bahwa motivasi kerja pegawai RSI Siti Rahmah Padang tergolong kedalam kategori rendah. ${ }^{11}$

\section{Komitmen Organisasi}

Komitmen organisasi merupakan identifikasi rasa, keterlibatan loyalitas yang ditampakkan oleh pekerja terhadap organisasinya atau unit organisasi. Variabel ini diukur dengan menggunakan 15 item pernyataan. Berdasarkan hasil análisis convergent validity ditemukan semua item pernyataan valid. Hasil analisis deskriptif terkait variabel komitmen organisasi Hasil dapat dilihat bahwa skor rata-rata variabel komitmen organisasi adalah 2,87 atau lebih Rendah dari nilai median yaitu 3.00. Hasil analisis deskriptif ini dapat diartikan bahwa komitmen organisasi yang dimiliki oleh pegawai RSI Siti Rahmah Padang tergolong kedalam kategori rendah. ${ }^{12}$

\section{Turnover Intention}

Turnover intention merupakan kecenderungan atau niat karyawan untuk meninggalkan pekerjaannya. Variabel ini diukur dengan menggunakan 5 item pernyataan. Berdasarkan hasil análisis convergent validity ditemukan semua item pernyataan valid. Hasil dapat dilihat bahwa skor rata-rata variabel turnover intention adalah 2,35 atau lebih rendah dari nilai median yaitu 2,00. Hasil analisis deskriptif ini dapat diartikan bahwa niat karyawan RSI Siti Rahmah Padang untuk meninggalkan pekerjaannya sekarang (turnover intention) tergolong kedalam kategori tinggi. ${ }^{13}$

\section{Model Struktural}

Hasil dapat dilihat bahwa variabel komitmen organisasi memiliki R Square $=0,688$ dan $\mathrm{R}$ Square Adjusted $=0,682$. Temuan ini bermakna bahwa besarnya pengaruh kepemimpinan dan motivasi kerja terhadap komitmen organisasi pada RSI Siti Rahmah Padang adalah 68,2\%, sementara sisanya $31.8 \%$ dipengaruhi oleh variabel lain yang tidak termasuk kedalam ruang lingkup penelitian ini. 9

Variabel turnover intention memiliki koefisien $\mathrm{R}$ Square sebesar 0.733 dan R Square Adjusted 0,725. Temuan ini bermakna bahwa besarnya pengaruh kepemimpinan, motivasi kerja, dan komitmen organisasi terhadap turnover intention pada RSI Siti Rahmah Padang adalah $72.5 \%$, sementara sisanya $27,7 \%$ dipengaruhi oleh variabel lain yang tidak termasuk kedalam ruang lingkup penelitian ini. ${ }^{9}$

\section{PEMBAHASAN}

\section{Pengaruh Kepemimpinan terhadap Turnover Intention}

Hasil pengujian hipotesis pertama ini memperlihatkan hubungan negatif antara variabel kepemimpinan dan variabel turnover intention ${ }^{10}$. Peningkatkan efektifitas kepemimpinan dapat dilakukan dengan meningkatkan kepercayaan atasan kepada bawahan untuk mengambil kebijakan non regular, mengadakan rapat koordinasi secara rutin dan atasan dapat memberikan umpan balik terhadap permasalahan yang dihadapi bawahan. ${ }^{14}$

Peningkatkan efektifitas kepemimpinan dapat dilakukan dengan meningkatkan kepercayaan atasan kepada bawahan untuk mengambil kebijakan non regular, mengadakan rapat koordinasi secara rutin dan atasan dapat memberikan umpan balik terhadap permasalahan yang dihadapi bawahan. ${ }^{14}$

\section{Pengaruh Motivasi Kerja terhadap Turnover Intention}

Hasil pengujian hipotesis kedua ini memperlihatkan hubungan negatif antara variabel motivasi kerja dan variabel turnover intention. Hal ini 
bermakna bahwa jika motivasi kerja dapat ditingkatkan maka secara langsung dapat menurunkan atau menekan keinginan karyawan meninggalkan RSI Siti Rahmah Padang. Namun sebaliknya jika motivasi kerja tidak mampu ditingkatkan maka secara langsung dapat meningkatkan atau menyebabkan munculnya keinginan karyawan meninggalkan RSI Siti Rahmah Padang. ${ }^{11}$

Motivasi kerja karyawan yang rendah di RSI Siti Rahmah disebabkan oleh beberapa hal yaitu: Masih banyak karyawan yang bekerja hanya semata - mata untuk mencari penghasilan yang layak saja, hal ini menyebabkan kurangnya loyalitas karyawan pada RSI Siti Rahmah. Masalah lain yaitu Pemberian reward yang masih belum jelas, Penghasilan yang masih rendah, perhatian atasan terhadap keluhan karyawan yang tidak ada, Cara atasan menunjukkan loyalitas agar bawahan merasa senang, Masih kurangnya jaminan hari tua dan jaminan kesehatan yang jelas untuk karyawan di RSI Siti Rahmah. ${ }^{11}$

\section{Pengaruh Komitmen Organisasi terhadap Turnover Intention}

Hipotesis ketiga $\left(\mathrm{H}_{3}\right)$ pada penelitian ini adalah "ada pengaruh kmitmen organisasi terhadap turnover intention pada RSI Siti Rahmah Padang". Hasil pengujian hipotesis ketiga ini memperlihatkan hubungan negatif antara variabel komitmen organisasi dan variabel turnover intention. Semakin tinggi komitmen organisasi yang dirasakan oleh karyawan, maka akan semakin rendah niat pindah kerja yang ditimbulkan oleh karyawan. ${ }^{16}$

Komitmen organisasi yang rendah disebabkan beberapa hal yaitu pada komitmen berkelanjutan, dimana komitmen berkelanjutan ini karyawan lebih mengutamakan untung ruginya bila karyawan berhenti bekeja dari RSI Siti Rahmah. Komitmen organisasi yang rendah menyebabkan karyawan masih berpikir untuk keluar dari RSI Siti Rahmah. ${ }^{16}$

\section{Pengaruh Kepemimpinan terhadap Komitmen Organisasi}

Hasil pengujian hipotesis keempat ini memperlihatkan hubungan positif antara variabel kepemimpinan dan variabel komitmen organisasi.
Kepemimpinan yang efektif dapat meningkatkan komitmen organisasi di RSI Siti Rahmah, sehingga dengan adanya peningkatan efektifitas kepemimpinan maka secara langsung dapat meningkatkan pula komitmen organisasi di RSI Siti Rahmah. Pada penelitian ini komitmen organisasi di RSI Siti Rahmah masih rendah ini juga dapat disebabkan masih kurang efektif kepemimpinan di RSI Siti Rahmah. ${ }^{17}$

Kepemimpinan yang efektif dapat meningkatkan komitmen organisasi di RSI Siti Rahmah, sehingga dengan adanya peningkatan efektifitas kepemimpinan maka secara langsung dapat meningkatkan pula komitmen organisasi di RSI Siti Rahmah. Pada penelitian ini komitmen organisasi di RSI Siti Rahmah masih rendah ini juga dapat disebabkan masih kurang efektif kepemimpinan di RSI Siti Rahmah. ${ }^{17}$

\section{Pengaruh Motivasi Kerja terhadap Komitmen Organisasi}

Hasil pengujian hipotesis kelima ini memperlihatkan hubungan positif antara variabel motivasi kerja dan variabel komitmen organisasi. Ada beberapa hal yang harus dilakukan untuk meningkatkan motivasi kerja di RSI Siti Rahmah yaitu dengan adanya peraturan rumah sakit yang jelas tentang reward dan funishment yang jelas sehingga karyawan merasa diperlakukan secara adil, jaminan hari tua karyawan lebih ditingkatkan lagi yaitu jaminan hari tua bukan hanya melalui jamsostek saja tetapi ada jaminan tambahan dari rumah sakit, karyawan juga lebih diperhatikan terkait fasilitas kerja yang dibutuhkan. ${ }^{15}$

Motivasi kerja di RSI Siti Rahmah masih rendah disebabkan karena karyawan merasa bahwa komitmen organisasi di RSI Siti Rahmah juga rendah. Ada beberapa hal yang harus dilakukan untuk meningkatkan motivasi kerja di RSI Siti Rahmah yaitu dengan adanya peraturan rumah sakit yang jelas tentang reward and punishment yang jelas sehingga karyawan merasa diperlakukan secara adil, jaminan hari tua karyawan lebih ditingkatkan lagi yaitu jaminan hari tua bukan hanya melalui jamsostek saja tetapi ada jaminan tambahan dari rumah sakit, karyawan juga lebih diperhatikan terkait fasilitas kerja yang dibutuhkan. ${ }^{15}$ 
Pengaruh Tidak Langsung

Pengaruh Kepemimpinan terhadap Turnover Intention yang Dimediasi oleh Komitmen Organisasi

Hasil analisis deskriptif menemukan skor ratarata variabel kepemimpinan sebesar 3,18 dan dapat diartikan bahwa implementasi kepemimpinan dilingkungan RSI Siti Rahmah Padang masuk kedalam kategori efektif. Skor rata-rata variabel komitmen organisasi adalah 2.87 atau dibawah nilai median (3.00). Hasil analisis deskriptif ini dapat diartikan bahwa komitmen organisasi yang dimiliki oleh pegawai RSI Siti Rahmah Padang masuk kedalam kategori rendah. Sedangkan skor rata-rata variabel turnover intention adalah 2.35 yang bermakna bahwa niat pegawai RSI Siti Rahmah Padang untuk keluar meninggalkan pekerjaan masuk kedalam kategori tinggi. Artinya apabila semakin efektif kepemimpinan itu adalah apabila masa yang akan datang RSI Siti Rahmah mampu memperbaiki atau meningkatkan kepemimpinan yang saat ini rata-ratanya 3.18 menjadi rata - rata menjadi 4.00, maka hal tersebut akan meningkatkan komitmen organisasi dari rendah menjadi tinggi, lalu selanjutnya akibat komitmen dapat menjadi tinggi maka hal itu member dampak menurunkan turnover intention. ${ }^{18}$

Hasil pengujian hipotesis keenam diketahui Variabel komitmen organisasi berperan sebagai variabel mediasi antara kepemimpinan dan turnover intention pada RSI Siti Rahmah Padang. Hasil penelitian ini bermakna bahwa apabila semakin efektif kepemimpinan yang diimplementasikan pada RSI Siti Rahmah Padang maka akan menyebabkan tingginya komitmen organisasi yang dimiliki oleh pegawai RSI Siti Rahmah Padang. Selanjutnya pegawai yang memiliki komitmen organisasi yang tinggi akan memberi dampak atau menyebabkan rendahnya keinginan pegawai untuk keluar meninggalkan organisasi. Namun sebaliknya, apabila semakin tidak efektif kepemimpinan yang terapkan pada RSI Siti Rahmah Padang maka akan menyebabkan rendahnya komitmen organisasi yang dimiliki oleh pegawai RSI Siti Rahmah Padang. Selanjutnya pegawai yang memiliki komitmen organisasi yang rendah akan memberi dampak atau menyebabkan tingginya keinginan pegawai untuk keluar meninggalkan organisasi (turnover inetntion). ${ }^{19}$

\section{Pengaruh Motivasi Kerja terhadap Turnover Intention yang Dimediasi oleh Komitmen Organisasi}

Hasil analisis deskriptif menemukan skor ratarata variabel motivasi kerja sebesar 2,97 dan dapat diartikan bahwa motivasi kerja yang dimiliki oleh pegawai RSI Siti rahmah Padang masuk kedalam kategori rendah. Skor rata-rata variabel komitmen organisasi adalah 2,87 atau dibawah nilai median (3.00). Hasil analisis deskriptif ini dapat diartikan bahwa komitmen organisasi yang dimiliki oleh pegwai RSI Siti Rahmah Padang masuk kedalam kategori rendah. Sedangkan skor rata-rata variabel turnover intention adalah 2,35 yang bermakna bahwa niat pegawai RSI Siti Rahmah Padang untuk keluar meninggalkan pekerjaan masuk kedalam kategori tinggi. Artinya apabila dimasa yang akan datang RSI Siti Rahmah dapat meningkatkan motivasi kerja karyawan, maka juga akan dapat meningkatkan komitmen organisasi. Selanjutnya pegawai yang memiliki komitmen organisasi yang rendah akan memberi dampak atau menyebabkan tingginya keinginan pegawai untuk keluar meninggalkan organisasi (turnover intention). ${ }^{20}$

Hasil pengujian hipotesis ketujuh diketahui bahwa variabel komitmen organisasi berperan sebagai variabel mediasi antara motivasi kerja dan turnover intention pada RSI Siti Rahmah Padang. Hasil penelitian ini bermakna bahwa apabila semakin tinggi motivasi kerja pegawai RSI Siti Rahmah Padang maka akan menyebabkan tingginya komitmen organisasi yang dimiliki oleh pegawai RSI Siti Rahmah Padang. Selanjutnya pegawai yang memiliki komitmen organisasi yang tinggi akan memberi dampak atau menyebabkan rendahnya keinginan pegawai untuk keluar meninggalkan organisasi. Namun sebaliknya, apabila semakin rendah motivasi kerja yang dimiliki oleh pegawai RSI Siti Rahmah Padang maka akan menyebabkan rendahnya komitmen organisasi yang dimiliki oleh pegawai RSI Siti Rahmah Padang 
Pegawai yang memiliki komitmen organisasi yang rendah akan memberi dampak atau menyebabkan tingginya keinginan pegawai untuk keluar meninggalkan organisasi (turnover intention). ${ }^{20}$

\section{SIMPULAN}

Kepemimpinan memiliki pengaruh yang positif terhadap komitmen organisasi pada RSI Siti Rahmah Padang.

Motivasi kerja memiliki pengaruh yang positif terhadap komitmen organisasi pada RSI Siti Rahmah Padang.

Komitmen organisasi terbukti sebagai variabel mediasi antara kepemimpinan dan turnover intention pada RSI Siti Rahmah Padang.

Komtimen organisasi terbukti sebagai variabel mediasi antara motivasi kerja dan turnover intention pada RSI Siti Rahmah Padang.

\section{SARAN}

Top dan Middle Manajemen perlu berupaya untuk lebih meningkatkan motivasi kerja dan komitmen organisasi dimasa yang akan datang pada pegawai RSI Siti Rahmah Padang.

\section{UCAPAN TERIMA KASIH}

Terima kasih kepada semua pihak yang telah memberikan bimbingan, saran, maupun kritikan dalam penelitian ini, serta pimpinan dan karyawan Rumah Sakit Islam Siti Rahmah.

\section{DAFTAR PUSTAKA}

1. Undang-Undang Nomor 44 Tahun 2009 Tentang Rumah Sakit. Jakarta: 2009.

2. Mangkunegara. Manajemen sumber daya manusia perusahaan. Bandung: PT Remaja Rosdakarya; 2013.hlm.64-7.

3. Astovi W, Sulianti D, Farida L. Pengaruh gaya kepemimpinan terhadap kompensasi kerja dan kinerja karyawan rumah sakit umum daerah Genteng Banyuwangi. Artikel IImiah Mahasiswa; 2016.hlm.1-4.

4. Utomo. Pengaruh kepemimpinan, motivasi kerja, disiplin kerja dan lingkungan kerja terhadap kinerja karyawan dan dosen STMIK Duta Bangsa
Surakarta. Jurnal Sainstech Politeknik Indonesia. 2014;1(4):125 -31.

5. Marwansyah. Manajemen sumber daya manusia. Bandung: Alfabeta; 2010.hlm.87-9.

6. Susanti, Palupiningdyah. Pengaruh kepuasan kerja dan komitmen organisasi terhadap kinerja karyawan dengan turnover intention sebagai variabel intervening. Jurnal Manajemen Fakultas Ekonomi Universitas Negeri Semarang. 2015;1(3): 77-86.

7. Sujarweni. Metodologi penelitan. Yogyakarta: PT. Pustaka Baru; 2014.hlm.56-8.

8. Ghazali I. Aplikasi analisis program PLS regresi dengan program SmartPLS. Semarang: Badan Penerbit di Universitas Diponegoro;2013.hlm.76-9.

9. Sekaran U. Research methods for business. (metodologi penelitian untuk bisnis). Jakarta: Salemba Empat; 2006.hlm.55-63.

10. Wibowo. Kepemimpinan, pemahaman dasar, pandangan konvensional, gagasan kontemporer. Jakarta: PT Raja Grafindo Persada; 2016. hlm. 48-51.

11. Hasibuan. Manajemen sumber daya manusia. Jakarta: PT Bumi Aksara; 2012.hlm.37-9.

12. Hasibuan. Organisasi dan motivasi. Jakarta: PT Bumi Aksara; 2014.hlm.86-9.

13. Witasari L. Analisis pengaruh kepuasan kerja dan komitmen organisasional terhadap turnover intentions (studi empiris pada Novotel Semarang). Jurnal Bisnis Strategi. April 2017;18(1):90-113.

14.Saklit IW. Pengaruh gaya kepemimpinan dan pengembangan karir terhadap intensi turnover: kepuasan kerja sebagai mediator. Jurnal Manajemen. 2017; XXI (03):472-90.

15. Purnama NQ, Sunuharyo BS, Prasetya A. Pengaruh motivasi kerja terhadap komitmen organisasional dan kinerja karyawan (studi pada karyawan bank BRI cabang Kawi Malang). Jurnal Administrasi Bisnis (JAB). Semarang. 2016;40(2): 39-47.

16. Putra PASW, Sariyathi NK. Pengaruh komitmen organisasi dan kepuasan kerja terhadap turnover intention di CV. Bengkel Bintang Pesona Grup. EJurnal Manajemen Unud. 2017; 6(2):579-603. 
17.Zahra. Pengaruh gaya kepemimpinan terhadap komitmen organisasi melalui aspek kepuasan kerja karyawan dan kepercayaan pada sektor perbankan. Jurnal Manajemen dan Pemasaran Jasa. Jakarta: 2015;8(1):145-51.

18. Gul S, Ahmad B, Rehman SU, Shabir N, Razzaq $\mathrm{N}$. Leadership styles, turnover intentions and the mediating role of organizational commitment. Information and Knowledge Management. 2012; 2 (7):44-51.
19. Shalahuddin A. Pengaruh kepemimpinan dan lingkungan kerja terhadap komitmen organisasional dan kinerja karyawan PT Sumber Djanin di Kalimantan Barat. Jurnal Manajemen Teori dan Terapan. April 2013;6(1):89-104.

20. Abdurrahim, HU Anisah. Pengaruh kepuasan kerja dan komitmen organisasi terhadap turnover intention karyawan pada PT Bank Perkreditan Rakyat Mitratama Arthabuana. Jurnal Wawasan Manajemen. Jakarta: 2015;3(3):191-8. 